\title{
The Apoptotic and Anti-apoptotic Effects of Pendimethalin and Trifluralin on A549 Cells In Vitro
}

\section{Pendimetalin ve Trifluralinin Apopitotik ve Anti-Apopitotik Etkilerinin A549 Hücrelerinde In Vitro Değerlendirilmesi}

\author{
(1) Zehra SARIGÖL-KILIÇ, (1) Ülkü ÜNDEĞER-BUCURGAT* \\ Hacettepe University, Faculty of Pharmacy, Department of Pharmaceutical Toxicology, Ankara, Turkey
}

\begin{abstract}
Objectives: Pendimethalin and trifluralin are commonly used in many countries to control broadleaf weeds and grassy weed species because of their inhibitor effects on growth and cell division. In this study, we examined the apoptotic and anti-apoptotic potentials of pendimethalin and trifluralin on A549 human non-small lung cancer cells with several concentrations in vitro.

Materials and Methods: The expression levels of apoptosis-related genes BCL-2, BAX, CAS3, CAS9, P53, BIRC, and PPIA were examined using quantitative RT-PCR after $24 \mathrm{~h}$ treatment of 1, 10, 50, 100 and $500 \mu \mathrm{M}$ pendimethalin and trifluralin.

Results: The effects of pendimethalin were found more repressive than trifluralin on all studied concentrations. Twenty-four hours' exposure with $100 \mu \mathrm{M}$ pendimethalin and trifluralin altered the gene expressions, suppressing apoptosis and allowing cancer cells to grow and proliferate.

Conclusion: Care should be taken not to exceed the permissible values and residue limits in food during pendimethalin and trifluralin use in order to reduce the possible carcinogenic effects on humans.
\end{abstract}

Key words: Pendimethalin, trifluralin, apoptosis, A549, gene expressions

Öz

Amaç: Pendimetalin ve trifluralin birçok ülkede, büyüme ve hücre bölünmesi üzerindeki inhibitör etkileri nedeniyle, geniş yapraklı yabani otları ve çimenli ot türlerini kontrol etmek amacıyla yaygın şekilde kullanılmaktadır. Bu çalışmada, pendimetalin ve trifluralinin apoptotik ve anti-apoptotik potansiyelleri, A549 insan küçük olmayan akciğer kanseri hücreleri üzerinde çeşitli konsantrasyonlarda in vitro incelendi.

Gereç ve Yöntemler: Apoptoz ile ilişkili genler BCL-2, BAX, CAS3, CAS9, P53, BIRC ve PPIA'nın ekspresyon seviyeleri, 24 saat 1, 10, 50, 100 ve 500 $\mu \mathrm{M}$ pendimetalin ve trifluralin uygulamasından sonra kantitatif RT-PCR ile incelendi.

Bulgular: Çalıșılan tüm konsantrasyonlarda pendimetalinin etkileri trifluralinin etkilerine kıyasla daha fazla baskılayıcı bulundu. $100 \mu \mathrm{M}$ pendimetalin ve trifluraline 24 saat boyunca maruz bırakılan hücrelerde gen ifadesi, apoptozu baskılayacak ve kanser hücrelerinin büyüme ve çoğalmasına yol açacak şekilde değişikliğe uğradı.

Sonuç: Pendimethalin ve trifluralinin insanlar üzerindeki olası kanserojenik etkilerini azaltabilmek için, kullanımları sırasında izin verilen değerlerin ve gıdalar üzerindeki kalıntı limitlerinin aşılmamasına dikkat edilmelidir.

Anahtar kelimeler: Pendimetalin, trifluralin, apopitoz, A549, gen ifadesi

*Correspondence: E-mail: uundeger@hacettepe.edu.tr, Phone: +90 5353685391 ORCID-ID: orcid.org/000-0002-6692-0366

Received: 20.07.2017, Accepted: 17.08.2017

๑Turk J Pharm Sci, Published by Galenos Publishing House. 


\section{INTRODUCTION}

Dinitroaniline herbicides were first discovered when dye and dye chemical intermediates were being evaluated. Chemicals in the dinitroaniline herbicide family essentially have a bright yellow color depending on the two nitro groups of the phenyl ring. They are generally referred to as "yellow compounds". The most important and the first herbicide in the dinitroaniline family is trifluralin, which became known in 1963. Dinitroaniline herbicides are separated into two groups as methylaniline herbicides and sulfonyllanine herbicides. Pendimethalin and trifluralin are herbicidal compounds in the group of methylaniline. ${ }^{2}$ Herbicides such as pendimethalin and trifluralin are used to control broadleaf weeds and grassy weed species in cabbage, celery, corn, cotton, garlic, lettuce, radish, rice, sorghum, tobacco, brassicas, carrots, cereals, citrus, onions, peas, peanuts, pome fruits, potatoes, soybeans, stone fruits, and tomatoes. Both herbicide compounds are also used in Turkey. Pendimethalin is used for growing apples, walnuts, hazelnuts, peanuts, potatoes, soy, citrus, grapes and asiatic seeds; trifluralin is used for growing cotton, soybean, sunflower seeds, sugar cane, citrus, tomatoes, peppers, onions, aubergine beans, carrots, cumin, and sesame in Turkey. ${ }^{3}$

Dinitroaniline group herbicide compounds pendimethalin and trifluralin can cause nitrosamine synthesis in animals and humans. Nitrozamines are highly reactive, harmful chemical species. They can act as carcinogenic substances by removing amino groups from the nucleotide bases of DNA. At the same time, they can act as toxic alkylating agents. ${ }^{2}$ For these reasons, cancer is the suspected health effect and the risk of dietary exposure to pendimethalin and trifluralin. Pendimethalin and trifluralin are also present as contaminants in soil, ground water, surface water, and air because of the widespread use of various formulations. ${ }^{4}$ Pendimethalin is classified as a slightly toxic compound (class 3 ) to mammals. Trifluralin has no acute toxicity on oral, dermal, and ocular exposures to mammals; although it is highly toxic to cold and warm water aquatic organisms as reported by the United States Environmental Protection Agency. Pendimethalin and trifluralin have also been classified as a group $\mathrm{C}$-possible human carcinogen. ${ }^{5}$

Apoptosis, programmed cell death, is defined by important morphologic changes; blebbing, chromatin condensation, nuclear fragmentation, and cell shrinkage. It is an essential process for normal development and also related to chronic diseases with various pathologic situations such as cardiovascular, immunologic, neurodegenerative diseases, and cancer. ${ }^{6}$

Apoptotic mechanism is activated with many biochemicals, the best-defined pathway factors are caspases. ${ }^{7}$ CAS3 is the main protease in the cell death process; CAS6 and CAS7 also contribute to the coordination of apoptosis. Thus, these three caspases are known the 'executioner caspases'. In addition, CAS8 and CAS9 play a role in the initiation step. ${ }^{8}$ When the initiative caspases activate the executioner caspases, the apoptotic process gets started with other enzyme activations. ${ }^{9}$ The apoptosis process continues on the extrinsic or intrinsic (mitochondrial) pathway and results in cell death.10 As well being a programmed process, apoptosis can occur after different kinds of irritations, such as radiation, anticancer drugs that cause DNA damage, and deprivation of cytokines that provide survival signals."

In addition to enzymatic changes, the apoptotic pathway is directly related to some gene expressions. As an example, BCL-2 family proteins control the intrinsic pathway on the antiapoptotic side; however, BAX and BAK proteins are promoters of cell death.12,13 One of the most important proteins at the cell cycle checkpoint is the $P 53$ tumor suppressor protein, which can be activated by DNA damage, hypoxia, and apoptosis. ${ }^{14}$

Pesticides are known to lead cells to apoptosis in both the intrinsic and extrinsic pathways. ${ }^{15-17}$ The compounds mainly enhance mitochondrial oxidative stress mediators and activate the cytochrome-C pathway, resulting in intrinsic apoptosis. ${ }^{18,19}$ Dinitroaniline herbicides are used as weed controllers. Their mechanisms of action are based on cell division and decreasing cell elongation and growth with mitotic disruption during mitosis. ${ }^{20,21}$

In this study, we measured the expression levels of P53, BAX, $B C L-2, C A S 3, C A S 9, B I R C$, and PPIA (housekeeping) genes related to apoptosis on $A 549$ human lung carcinoma cells after exposure to pendimethalin and trifluralin, which are two commonly used dinitroaniline herbicides.

\section{MATERIALS AND METHODS}

\section{Solution preparation}

Pendimethalin is highly soluble in oil and organic solvents. ${ }^{22}$ The solution was prepared in a dimethyl sulfoxide (DMSO):olive oil (1:3, v/v) mix. Trifluralin is soluble in organic solvents and less soluble in water. ${ }^{23}$ The trifluralin solution was prepared in PBS (1\% DMSO).

Dulbecco's Modified Eagle's medium with $10 \%$ fetal calf serum and a $1 \%$ penicillin-streptomycin mixture were used as the cell culture medium.

\section{Cell culture and treatment}

A549 cells were cultured in a $25-\mathrm{cm}^{2}$ cell culture flask and transferred to a $75-\mathrm{cm}^{2}$ flask after $24 \mathrm{~h}$ under the conditions of $5 \% \mathrm{CO}_{2}$ and $37^{\circ} \mathrm{C}$. After 24 hours, the cells were harvested and transferred to 6 -well plates as 10,000 cell/2 $\mathrm{mL}$ medium of each. Cell counts were performed using Tripan blue $(0.4 \%$ $\mathrm{w} / \mathrm{v}$ in distilled water) in a Neubauer Chamber. One day later, when the cell count multiplied 2 folds and reached 20,000/ well, pendimethalin and trifluralin solutions were added to the wells, the final concentrations were 1,10,50, 100 and $500 \mu \mathrm{M}$. These concentrations were chosen according to their $50 \%$ inhibitory concentration $\left(\mathrm{IC}_{50}\right)$ and toxicity levels. ${ }^{24-27}$ The cells were incubated for 24 hours and harvested from the wells and centrifuged at $1200 \mathrm{rpm}$ for $5 \mathrm{~min}$.

\section{RNA isolation, cDNA synthesis and gene expression}

RNA isolation were performed using an RNeasy Mini Kit, QIAGEN in accordance with the manufacturer's instructions. In brief, after centrifugation, the cell suspension was filtrated 
from the gDNA eliminator column, then transferred and attached to the RNeasy spin column and washed with the solutions as instructed.

The amount and quality of the eliminated RNA samples were measured using Maestrogen Nanodrop. For this measurement, $1 \mu \mathrm{L}$ of the sample was loaded to the base portion fiber terminal. All the samples' OD 260/280 ratios were found in the range of 1.6-1.8.

The cDNA synthesis was performed from the RNA samples with $\mathrm{RT}^{2}$ First Strand Kit, QIAGEN as per the manufacturer's instructions. The RNA samples were denaturized at $42^{\circ} \mathrm{C}$ for 5 $\mathrm{min}$ in a real-time quantitative reverse transcription polyeramse chain reaction (qRT-PCR) device. The samples were placed on a cold surface to protect the linearity. Then reverse-transcription enzymes were added and the cDNA synthesis process was performed at $42^{\circ} \mathrm{C}$ for 15 minutes and $90^{\circ} \mathrm{C}$ for 5 minutes. Newly synthesized cDNA samples were stored at $-20^{\circ} \mathrm{C}$. The PCR primers used in this study are listed in Table 1.

To measure the expression levels of apoptosis-related genes, cDNA samples were mixed with $\mathrm{RT}^{2}$ qPCR primers $(B C L-2$, $B A X, C A S 3, C A S 9, P 53, B I R C$ and PPIA), RT2 SYBR Green qPCR mastermix, and expression was performed using the qRT-PCR device under the conditions of hold $95^{\circ} \mathrm{C} 15 \mathrm{~min}$, cycle $95^{\circ} \mathrm{C} 15$ sec and $60^{\circ} \mathrm{C} 30 \mathrm{sec}$, for 40 cycles. The results were recorded at $60^{\circ} \mathrm{C}$. The threshold limit was set to 0.05 and the $\mathrm{Ct}$ values of the samples were calculated.

The results of this article were prepared on performed in vitro cultured cells study. Therefore, there is no need for ethics committee approval.

\section{Statistical analysis}

Statistics of the Ct values were prepared with an internetbased program RT2 Profiler PCR Data Analysis 3.5. $\Delta \Delta \mathrm{Ct}$ was used to interpret the gene expression data. ${ }^{28}$ All experiments were performed twice.

\section{RESULTS}

The average $\mathrm{Ct}$ (mean), average $\triangle \Delta \mathrm{CT}$, and fold regulation (updown regulation) values of the $A 549$ cell line after exposure to pendimethalin and trifluralin for $24 \mathrm{~h}$ were calculated. $\triangle \mathrm{Ct}$ calculation was preferred to normalize the raw data and Ct value of the housekeeping gene, PPIA, was used as the normalization factor. Fold regulation is the ratio of the relative gene expression between the housekeeping gene and the treatment group. This calculation illustrated the up- and downregulated expressions within $p<0.05$ significance. The formulas used for the calculations were as follows:

$\Delta \mathrm{Ct}=\mathrm{Ct}$ (gene of interest) - average [Ct (housekeeping / reference gene)]

$\Delta \Delta \mathrm{Ct}=\Delta \mathrm{Ct}$ (test group $\mathrm{n})-\Delta \mathrm{Ct}$ (control group)

Average $\Delta \mathrm{Ct}=[\Delta \mathrm{Ct}$ (sample 1$)+\Delta \mathrm{Ct}$ (sample 2$)+\ldots \Delta \mathrm{Ct}$ (sample n)] / n samples

Average $\Delta \Delta \mathrm{Ct}=2^{(- \text {Average } \Delta \mathrm{Ct})}$

Fold regulation $=2^{(-\Delta \Delta C t)}$

The results are presented in Tables 2-7.
Due to the fold regulation results of trifluralin, all gene expressions were down-regulated at the examined concentrations (1-500 $\mu \mathrm{M})$. However, pendimethalin showed different regulation profiles in the same genes. The concentrations of 100 and 500

Table 1. The PCR primers used in this study

\begin{tabular}{|c|c|}
\hline \multirow{2}{*}{ P53 } & 5'-CCCAGCCAAAGAAGAAACCA-3'- (fwd) \\
\hline & 5'-TTCCAAGGCCTCATTCAGCT-3'(rv) \\
\hline \multirow[b]{2}{*}{ BIRC5 } & 5'AGAACTGGCCCTTCTTGGAGG-3'-(fwd) \\
\hline & 5'-CTTTTTATGTTCCTCTATGGGGTC-3' (rv) \\
\hline \multirow[b]{2}{*}{$B A X$} & 5'-TGCTTCAGGGTTTCATCCAG-3' (fwd) \\
\hline & 5'-GGCGGCAATCATCCTCTG-3'(rv) \\
\hline \multirow[b]{2}{*}{$B C L-2$} & 5'-AGGAAGTGAACATTTCGGTGAC-3' (fwd) \\
\hline & 5'-GCTCAGTTCCAGGACCAGGC-3'(rv) \\
\hline \multirow[b]{2}{*}{ CAS3 } & 5'ACATGGCGTGTCATAAAATACC-3' (fwd) \\
\hline & 5'-CACAAAGCGACTGGATGAAC-3'(rv) \\
\hline \multirow[b]{2}{*}{ CAS9 } & 5'-CCAGAGATTCGCAAACCAGAGG-3' (fwd) \\
\hline & 5'-GAGCACCGACATCACCAAATCC-3'(rv) \\
\hline \multirow{2}{*}{ Housekeeping PPIA } & 5'AAGGGTTCCTGCTTTCAC-3' (fwd) \\
\hline & 5'-GGACCCGTATGCTTTAGG-3' (rv) \\
\hline
\end{tabular}

Table 2. Average $\mathrm{Ct}$ values of pendimethalin

\begin{tabular}{lllllll}
\multicolumn{7}{l}{ AVG Ct pendimethalin } \\
\hline Symbol & Control & PM 500 & PM 100 & PM 50 & PM 10 & PM 1 \\
\hline BAX & 19.48 & 34.74 & 33.89 & 25.66 & 23.81 & 19.97 \\
\hline BCL-2 & 26.87 & 30.87 & 30.88 & 29.97 & 28.94 & 24.98 \\
\hline BIRC5 & 25.79 & 33.95 & *N/A & 31.78 & 29.99 & 22.99 \\
\hline P53 & 20.35 & 34.43 & 34.85 & 26.59 & 26.04 & 19.93 \\
\hline CAS3 & 22.79 & $*$ N/A & *N/A & 28.57 & 25.94 & 22.05 \\
\hline CAS9 & 24.27 & $*$ N/A & 33.31 & 30.22 & 25.7 & 22.9 \\
\hline PPIA & 25.03 & $*$ N/A & *N/A & 27.48 & 26.36 & 22.27 \\
\hline
\end{tabular}

*N/A greater than 35

Table 3. Average $\Delta \Delta \mathrm{Ct}$ values of pendimethalin

\begin{tabular}{lllllll}
$2^{\text {(-Average } \triangle C t)}$ pendimethalin & & & & & \\
\hline Symbol & Control & PM 500 & PM 100 & PM 50 & PM 10 & PM 1 \\
\hline BAX & 47.01 & 1.20 & 2.17 & 3.53 & 5.86 & 4.92 \\
\hline BCL-2 & 0.28 & 17.57 & 17.39 & 0.18 & 0.17 & 0.15 \\
\hline BIRC5 & 0.59 & 2.07 & 1.00 & 0.05 & 0.08 & 0.61 \\
\hline P53 & 25.72 & 1.49 & 1.11 & 1.86 & 1.24 & 5.06 \\
\hline CAS3 & 4.74 & 1.00 & 1.00 & 0.47 & 1.33 & 1.16 \\
\hline CAS9 & 1.69 & 1.00 & 3.24 & 0.15 & 1.58 & 0.65 \\
\hline PPIA & 1.00 & 1.00 & 1.00 & 1.00 & 1.00 & 1.00 \\
\hline
\end{tabular}


Table 4. Fold regulation (up-down) values of pendimethalin

Up-down regulation (comparing to control group) pendimethalin

\begin{tabular}{|c|c|c|c|c|c|}
\hline & PM 500 & PM 100 & PM 50 & PM 10 & PM 1 \\
\hline Symbol & Fold regulation & Fold regulation & Fold regulation & Fold regulation & Fold regulation \\
\hline$B A X$ & $-39.1245^{\star}$ & $-21.7057^{\star}$ & $-13.3152^{*}$ & $-8.0278^{*}$ & $-9.5467^{*}$ \\
\hline$B C L$ & $62.6829 * \star$ & $62.0345^{\star \star}$ & $-1.5692 * \star *$ & $-1.6818^{\star \star \star}$ & $-1.834^{\star \star \star}$ \\
\hline BIRC5 & $3.4943^{* *}$ & $1.6876^{\star \star \star}$ & -11.6318 & -7.336 & $1.0281^{\star \star \star}$ \\
\hline P53 & $-17.2677^{\star}$ & $-23.1831^{*}$ & $-13.8326^{*}$ & $-20.6776^{\star}$ & $-5.0806^{\star}$ \\
\hline CAS3 & $-4.7404^{\star}$ & $-4.7404^{\star}$ & $-10.0561^{\star}$ & $-3.5554^{*}$ & $-4.0699 *$ \\
\hline CAS9 & $-1.6935^{\star \star \star}$ & $1.9119 * \star \star$ & $-11.2746^{*}$ & $-1.0718^{\star \star \star}$ & $-2.6208^{*}$ \\
\hline PPIA & 1 & 1 & 1 & 1 & 1 \\
\hline
\end{tabular}

*Down regulated expression compared with the control group (PPIA) $p<0.05$

**Up regulated expression compared with the control group (PPIA) $p<0.05$

$\star * \star$ No significant changes observed compared with the control group

\section{Table 5. Average $\mathrm{Ct}$ values of trifluralin}

AVG Ct trifluralin

\begin{tabular}{|c|c|c|c|c|c|c|}
\hline Symbol & Control group & TF 500 & TF 100 & TF 50 & TF 10 & TF 1 \\
\hline$B A X$ & 19.48 & 22.83 & 18.29 & 18.12 & 18.79 & 18.35 \\
\hline$B C L$ & 26.87 & 28.78 & 25.21 & 25.78 & 26.36 & 25.97 \\
\hline BIRC5 & 25.79 & 29.42 & 24.85 & 24.52 & 24.49 & 23.77 \\
\hline P53 & 20.35 & 24.86 & 19.87 & 19 & 19.7 & 19.33 \\
\hline CAS3 & 22.79 & 26.05 & 21.41 & 21.9 & 22.77 & 22.33 \\
\hline CAS9 & 24.27 & 26.12 & 22.55 & 22.65 & 23.21 & 23.16 \\
\hline PPIA & 25.03 & 24.96 & 20.74 & 20.26 & 20.94 & 21.07 \\
\hline
\end{tabular}

Table 6. Average $\Delta \Delta \mathrm{Ct}$ values of trifluralin

$2^{\text {(-Average } \Delta C t)}$ trifluralin

\begin{tabular}{lllllll}
\hline Symbol & Control group & TF 500 & TF 100 & TF 50 & TF 10 & TF 1 \\
\hline BAX & 47.01 & 4.38 & 5.45 & 4.42 & 4.44 & 6.61 \\
\hline BCL-2 & 0.28 & 0.07 & 0.05 & 0.02 & 0.02 & 0.03 \\
\hline BIRC5 & 0.59 & 0.05 & 0.06 & 0.05 & 0.09 & 0.15 \\
\hline P53 & 25.72 & 1.07 & 1.83 & 2.39 & 2.35 & 3.35 \\
\hline CAS3 & 4.74 & 0.47 & 0.63 & 0.32 & 0.28 & 0.42 \\
\hline CAS9 & 1.69 & 0.45 & 0.28 & 0.19 & 0.21 & 0.24 \\
\hline PPIA & 1.00 & 1.00 & 1.00 & 1.00 & 1.00 & 1.00 \\
\hline
\end{tabular}

$\mu \mathrm{g} / \mathrm{mL}, B C L-2$ gene, and on $500 \mu \mathrm{g} / \mathrm{mL}$ BIRC5 gene expressions were found up-regulated compared with the PPIA control gene, whereas other concentrations of pendimethalin the examined genes are down-regulated.

\section{DISCUSSION}

Pesticide use has brought about both positive and negative results on human health and the environment. They led to an increase of the amount and quality of agricultural products, along with various health problems and disruption of the soil and water. In this study, we determined the changes of apoptosis-related gene expressions with dinitroaniline herbicides. After $24 \mathrm{~h}$ of incubation, at the concentration of $100 \mu \mathrm{M}$, pendimethalin significantly down-regulated $B A X, P 53$, and CAS3. Although CAS9 levels showed no significant change, BCL-2 and BIRC5 levels were up-regulated with pendimethalin exposure. On the other hand, trifluralin exposure down-regulated all examined gene levels at all concentrations. It has been shown that P53 is essential for normal cell apoptosis regulation because of its ability to control $B A X$ regulation - the proapoptoic member of the BCL-2 family. ${ }^{29}$ Decreased $P 53$ levels gave rise to cellular viability, lifespan, and chromosomal instability. ${ }^{30}$ It can be stated that increased $B C L-2$ expressions come with a decrease of $P 53$ and $B A X$ levels and prevent $A 549$ cells from entering apoptosis. Also, $B A X$ can induce caspase activation and increase cellular reactive oxygen species (ROS) by caspase cleavage..$^{31}$ Studies demonstrated that CAS3 activation mediated the $B A X$-mediated pro-oxidant effects ${ }^{32}$ and had an important role on inducing apoptosis via the mitochondrial cascade. ${ }^{33}$ In our study, CAS3 expressions were found down-regulated with $B A X$, which in turn lowered the probability of apoptosis on A549 non-small lung cancer cells. 
Table 7. Fold regulation (up-down) values of trifluralin

Up-down regulation (comparing to control group) trifluralin

\begin{tabular}{|c|c|c|c|c|c|}
\hline & TF 500 & TF 100 & TF 50 & TF 10 & TF 1 \\
\hline Symbol & Fold regulation & Fold regulation & Fold regulation & Fold regulation & Fold regulation \\
\hline$B A X$ & $-10.7406^{*}$ & $-8.6338^{\star}$ & $-10.6295^{*}$ & $-10.5927^{\star}$ & $-7.1107^{\star}$ \\
\hline$B C L-2$ & $-3.9449 *$ & $-6.2118^{*}$ & $-12.8616^{*}$ & $-12.0003^{*}$ & $-8.3397^{\star}$ \\
\hline BIRC5 & $-13.0412^{*}$ & $-10.2319^{*}$ & $-11.3137^{\star}$ & $-6.9644^{*}$ & $-3.8504^{\star}$ \\
\hline CAS3 & $-10.091^{*}$ & $-7.5685^{\star}$ & $-14.7741^{*}$ & $-16.8538^{*}$ & $-11.3137^{\star}$ \\
\hline CAS9 & $-3.7842^{*}$ & $-5.9587^{\star}$ & $-8.8766^{\star}$ & $-8.1965^{\star}$ & $-7.1851^{*}$ \\
\hline PPIA & 1 & 1 & 1 & 1 & 1 \\
\hline
\end{tabular}

*Downregulated expression compared with the control group (PPIA) $p<0.05$

**Upregulated expression compared with the control group (PPIA) p<0.05

$\star * *$ No significant changes observed compared with the control group

Caspases can initiate the degradation phase of apoptosis with DNA fragmentation and blebbing. ${ }^{34}$ CAS9 inhibition was shown to decrease the ROS production in mitochondria, ${ }^{35}$ and the upregulation resulted with induced $\mathrm{ROS}$ production and activation of CAS3 and CAS7.36

BIRC5 (survivin) showed different effects with herbicide exposure at the concentration of $100 \mu \mathrm{M}$. Although pendimethalin caused up-regulation, trifluralin exposure down-regulated $B I R C 5$ levels significantly. It is known that BIRC5 is responsible for cell division regulation during the $G_{1}-S$ phase and it is also considered for anticancer therapies. ${ }^{37}$ Expressed levels of BIRC5 were found higher than in normal healthy cells in various tumors such as lung, breast, ovarian, and prostate cancers. ${ }^{38-41}$ One study stated that BIRC5 silencing suppressed cell proliferation in A549 non-small lung cancer cells. ${ }^{38}$ Compared with our results, we can state that even though pendimethalin reduced apoptotic cycles with BIRC5 up-regulation, trifluralin exposure could not deactivate programmed cell death in A549 cells at the BIRC5 level.

\section{CONCLUSIONS}

According to our findings and those of previous studies, pendimethalin and trifluralin exposure resulted with reducedapoptosis, which in turn lead to tumor growth in A549 cells in vitro. As stated before, both herbicides significantly changed the expression levels, but pendimethalin had more effects on anti-apoptosis than trifluralin. This study found that tumor suppression genes can be altered by environmental exposure and further studies will enlighten us about the connection between dinitroaniline herbicides and lung cancer.

\section{ACKNOWLEDGEMENTS}

This work was supported by the Hacettepe BAP under Grant number 1603.

Conflict of Interest: No conflict of interest was declared by the authors.

\section{REFERENCES}

1. Wallace DR. Trifluralin in Encyclopedia of Toxicology. In: Wexler P, ed. Encyclopedia of Toxicology, 3rd ed. Oxford; Academic Press; 2014:388389.

2. Agronomy 317, Intro to Weeds, "Dinitroanilines", Accessed: 03.02.1017, Available via "http://agron.iastate.edu/-weeds/Ag317-99/manage/ herbicide/dnas.html".

3. T.C. Milli Eğitim Bakanlığı, Çevre Sağlığı, Pestisitler, 850 CK 0054 Ankara, 2012.

4. Kegley S, Hill B, Orme S. Pendimethalin. PAN Pesticide Database, Pesticide Action Network, North America, San Francisco, CA. Accessed 23.12.2015, Available via" http://www.pesticideinfo.org".

5. US Environmental Protection Agency (US EPA), R.E.D. Facts: Pendimethalin, US EPA; Washington DC; 1997.

6. Zimmermann KC, Green DR. How cells die: Apoptosis pathways. J Allergy Clin Immunol 2001;108:99-103.

7. Martin SJ, Green DR. Protease activation during apoptosis: death by a thousand cuts? Cell. 1995;82:349-352.

8. Mcllwain DR, Berger T, Mak TW. Caspase functions in cell death and disease. Cold Spring Harb Perspect Biol. 2013;5:a008656.

9. Riedl SJ, Shi Y. Molecular mechanisms of caspase regulation during apoptosis. Nat Rev Mol Cell Biol. 2004;5:897-907.

10. Vermeulen K, Van Bockstaele DR, Berneman ZN. Apoptosis: mechanisms and relevance in cancer. Ann Hematol. 2005;84:627-639.

11. Kataoka S, Tsuruo T. Physician Education: Apoptosis. Oncologist. 1996;1:399-401.

12. Wei MC, Zong WX, Cheng EH, Lindsten T, Panoutsakopoulou V, Ross AJ, Roth KA, MacGregor GR, Thompson CB, Korsmeyer SJ. Proapoptotic BAX and BAK: a Requisite Gateway to Mitochondrial Dysfunction and Death. Science. 2001;292:727-730.

13. Cory S, Adams JM. The Bcl2 family: regulators of the cellular life-ordeath switch, Nat Rev Cancer. 2002;2:647-656.

14. Hussain SP, Harris CC. Molecular epidemiology of human cancer: contribution of mutation spectra studies of tumor suppressor genes. Cancer Res. 1998:58:4023-4037. 
15. Chi CC, Chou CT, Liang WZ, Jan CR. Effect of the pesticide, deltamethrin, on $\mathrm{Ca} 2+$ signaling and apoptosis in OC2 human oral cancer cells. Drug Chem Toxicol. 2014;37:25-31.

16. Raszewski G, Lemieszek MK, Lukawski K, Juszczak M, Rzeski W. Chlorpyrifos and cypermethrin induce apoptosis in human neuroblastoma cell line SH-SY5. Basic Clin Pharmacol Toxicol. 2015;116:158-167.

17. Jang Y, Lee AY, Jeong SH, Park KH, Paik MK, Cho NJ, Kim JE, Cho MH. Chlorpyrifos induces NLRP3 inflammasome and pyroptosis/apoptosis via mitochondrial oxidative stress in human keratinocyte HaCaT cells. Toxicology. 2015;338:37-46.

18. Banerjee BD, Seth V, Ahmed RS. Pesticide-induced oxidative stress: perspectives and trends. Rev Environ Health. 2001;16:1-40.

19. Li Q, Kobayashi M, Kawada T. Carbamate pesticide-induced apoptosis and necrosis in human natural killer cells. J Biol Regul Homeost Agents. 2014:28:23-32.

20. Nick P. Control of plant shape, In Plant Microtubules: Potential for Biotechnology. Nick P, ed. Berlin- Heidelberg; Springer BerlinHeidelberg; 2000:25-50.

21. Tresch S, Plath P, Grossmann K. Herbicidal cyanoacrylates with antimicrotubule mechanism of action. Pest Manag Sci. 2005;61:10521059.

22. EXTOXNET, Extension Toxicology Network Pesticide Information Profiles: Pendimethalin, 1996a. Accessed 23.12.2015, Available via http:// extoxnet.orst.edu/pips/pendimet.htm

23. EXTOXNET. Extension Toxicology Network Pesticide Information Profiles: Trifluralin, 1996b. Accessed 23.12.2015, Available via http:// extoxnet.orst.edu/pips/triflura.htm

24. Dimitrov BD, Gadeva PG, Benova DK, Bineva MV. Comparative genotoxicity of the herbicides Roundup, Stomp and Reglone in plant and mammalian test systems. Mutagenesis. 2006;21:375-382.

25. Patel S, Bajpayee M, Pandey AK, Parmar D, Dhawan A. In vitro induction of cytotoxicity and DNA strand breaks in $\mathrm{CHO}$ cells exposed to cypermethrin, pendimethalin and dichlorvos. Toxicol In Vitro. 2007;21:1409-1418.

26. Zaidenberg A, Marra C, Luong T, Gomez P, Milani L, Villagra S, Drut R. Trifluralin toxicity in a Chagas disease mouse model. Basic Clin Pharmacol Toxicol. 2007;101:90-95.

27. Weir SM, Yu S, Salice CJ. Acute toxicity of herbicide formulations and chronic toxicity of technical-grade trifluralin to larval green frogs (Lithobates clamitans). Environ Toxicol Chem. 2012;31:2029-2034.

28. Livak KJ, Schmittgen TD. Analysis of Relative Gene Expression Data Using Real-Time Quantitative PCR and the 2-(-Delta Delta C(T)) Method. Methods. 2001;25:402-408.
29. Fridman JS, Lowe SW. Control of apoptosis by p53. Oncogene. 2003;22:9030-9040.

30. Lowe SW, Lin AW. Apoptosis in cancer. Carcinogenesis. 2000;21:485495.

31. Ricci JE, Munoz-Pinedo C, Fitzgerald P, Bailly-Maitre B, Perkins GA, Yadava N, Scheffler IE, Ellisman MH, Green DR. Disruption of mitochondrial function during apoptosis is mediated by caspase cleavage of the p75 subunit of complex I of the electron transport chain. Cell. 2004:117:773-786.

32. Kirkland RA, Franklin J. Bax and caspases regulate increased production of mitochondria-derived reactive species in neuronal apoptosis: LACK of $A$ role for depletion of cytochrome $c$ from the mitochondrial electron transport chain. Biochem Biophys Rep. 2015;4:158-168.

33. Chakraborty S, Mazumdar M, Mukherjee S, Bhattacharjee P, Adhikary A, Manna A, Chakraborty S, Khan P, Sen A, Das T. Restoration of p53/ miR-34a regulatory axis decreases survival advantage and ensures Baxdependent apoptosis of non-small cell lung carcinoma cells. FEBS Lett. 2014;588:549-559.

34. Srinivasula SM, Ahmad M, Fernandes-Alnemri T, Alnemri ES. Autoactivation of procaspase-9 by Apaf-1-mediated oligomerization. Mol Cell. 1998;1:949-957.

35. Cepero E, King AM, Coffey LM, Perez RG, Boise LH. Caspase-9 and effector caspases have sequential and distinct effects on mitochondria. Oncogene. 2005;24:6354-6366.

36. Brentnall M, Rodriguez-Menocal L, De Guevara RL, Cepero E, Boise LH. Caspase- 9 , caspase- 3 and caspase- 7 have distinct roles during intrinsic apoptosis. BMC Cell Biol. 2013;14:1-9.

37. Wheatley SP, McNeish IA. Survivin: a protein with dual roles in mitosis and apoptosis. Int Rev Cytol. 2005;247:35-88.

38. Monzo M, Rosell R, Felip E, Astudillo J, Sanchez JJ, Maestre J, Martin C, Font A, Barnadas A, Abad A. A novel anti-apoptosis gene: Re-expression of survivin messenger RNA as a prognosis marker in non-small-cell lung cancers. J Clin Oncol. 1999;17:2100-2104.

39. Tanaka K, Iwamoto S, Gon G, Nohara T, Iwamoto M, Tanigawa N. Expression of survivin and its relationship to loss of apoptosis in breast carcinomas. Clin Cancer Res. 2000;6:127-134.

40. Krajewska M, Krajewski S, Banares S, Huang X, Turner B, Bubendorf L, Kallioniemi OP, Shabaik A, Vitiello A, Peehl D, Gao GJ, Reed JC. Elevated expression of inhibitor of apoptosis proteins in prostate cancer. Clin Cancer Res. 2003;9:4914-4925.

41. Xing J, Jia CR, Wang Y, Guo J, Cai Y. Effect of shRNA targeting survivin on ovarian cancer. J Cancer Res Clin Oncol. 2012;138:1221-1229. 